\begin{tabular}{|c|c|c|c|c|}
\hline \multicolumn{5}{|l|}{$\left[\mathrm{Zn}^{2+}\right]$ in the } \\
\hline dialysis & & {$\left[\mathrm{Zn}^{2+}\right](\mu \mathrm{g} / \mathrm{l})$} & {$\left[\mathrm{Zn}^{2+}\right](\mu \mathrm{M})$} & $\mathrm{Zn} / \mathrm{CphAII}$ \\
\hline buffer & & & & ratio \\
\hline \multirow[t]{3}{*}{$<0.4 \mu \mathrm{M}$} & Dialyzed CphAII sample & 981 & 15 & \\
\hline & Dialysis buffer & $<10$ & $<0.15$ & \\
\hline & $\Rightarrow$ CphAII $(15 \mu \mathrm{M})$ & $=981-10$ & 14.9 & 1 \\
\hline \multirow[t]{3}{*}{$100 \mu \mathrm{M}$} & Dialyzed CphAII sample & 8032 & 124 & \\
\hline & Dialysis buffer & 6147 & 95 & \\
\hline & $\rightarrow$ CphAII $(15 \mu \mathrm{M})$ & $=8032-6147$ & 29 & 1.9 \\
\hline
\end{tabular}

Table 1. Determination of the Zn/enzyme content by ICP/MS. 


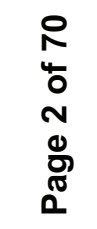

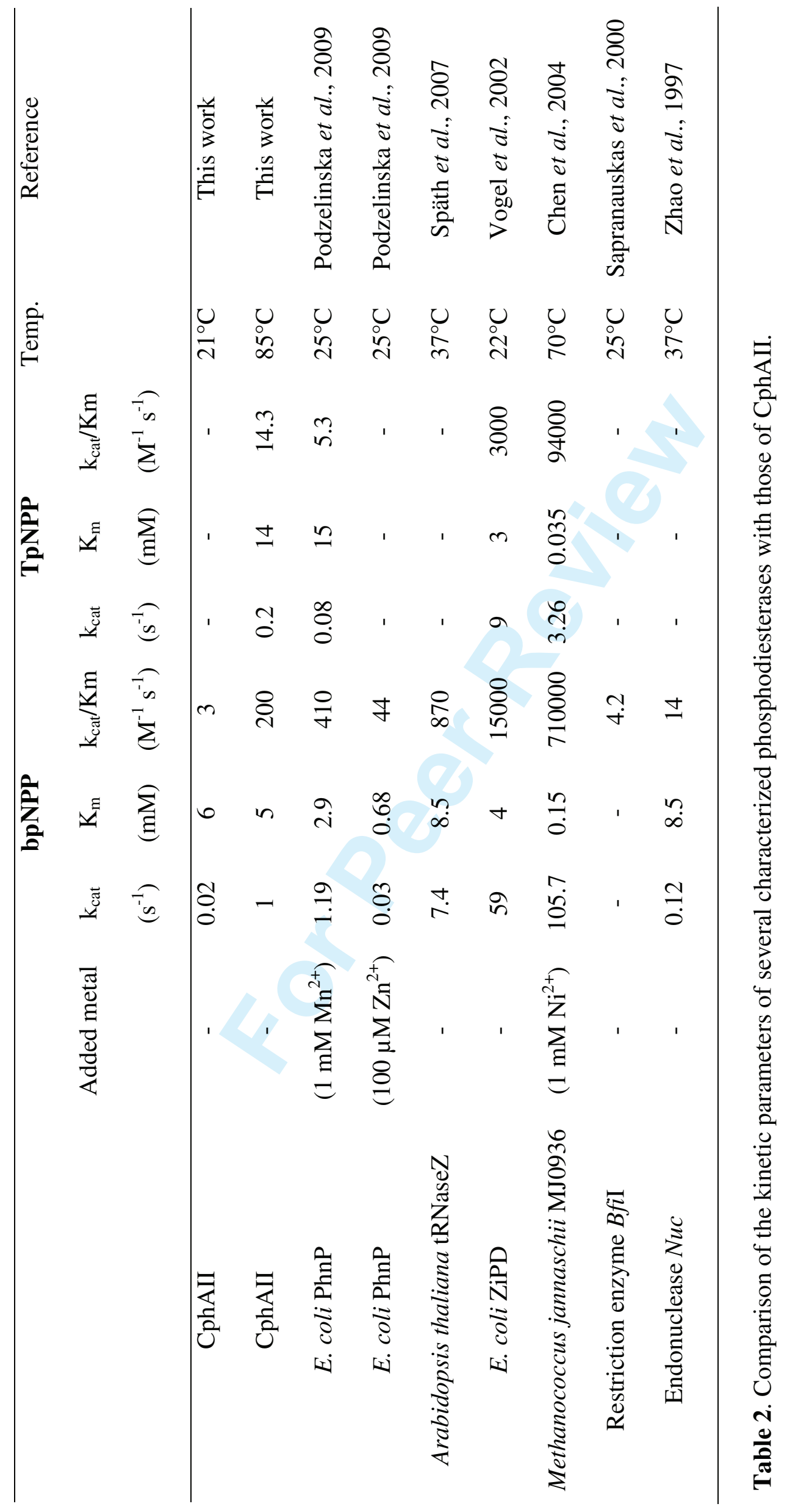




\section{The CphAII protein from Aquifex aeolicus exhibits a metal-dependent phosphodiesterase activity.}

Michaël Kupper ${ }^{1}$, Cédric Bauvois ${ }^{2}$, Jean-Marie Frère ${ }^{3}$, Kurt Hoffmann ${ }^{1}$, Moreno Galleni ${ }^{4}$ and Carine Bebrone $e^{1,4 *}$.

${ }^{1}$ Institute of Molecular Biotechnology, RWTH-Aachen University, Forckenbeckstraße 6, 52074 Aachen, Germany

${ }^{2}$ Cristallographie des protéines, Institut de Recherches Microbiologiques J.-M. Wiame IRMW, Campus CERIA - Av. E. Gryson, 1, B-1070 Bruxelles, BELGIUM

${ }^{3}$ Centre for Protein Engineering (CIP), University of Liège, Allée du 6 Août B6, Sart-Tilman 4000 Liège, Belgium

${ }^{4}$ Biological macromolecules, CIP, University of Liège, Allée du 6 Août B6, Sart-Tilman, 4000 Liège, Belgium

* Corresponding author: Carine Bebrone, Institute of Molecular Biotechnology, RWTHAachen University, Forckenbeckstraße 6, 52074 Aachen, Germany, Tel.: 0049-241608513421, carine.bebrone@molbiotech.rwth-aachen.de 


\begin{abstract}
The CphAII protein from the hyperthermophile Aquifex aeolicus shows the five conserved motifs of the metallo- $\beta$-lactamase superfamily and presents $28 \%$ identity with the Aeromonas hydrophila subclass B2 CphA metallo- $\beta$-lactamase. The gene encoding CphAII was amplified by PCR from the A. aeolicus genomic DNA and overexpressed in Escherichia coli using a pLex-based expression system. The recombinant CphAII protein was purified by a combination of heating (to denature E. coli proteins) and two steps of immobilised metal affinity chromatography. The purified enzyme preparation did not exhibit a $\beta$-lactamase activity but showed a metal-dependent phosphodiesterase activity versus bis-p-nitrophenyl phosphate and thymidine $5^{\prime}$-monophosphate $p$-nitrophenyl ester, with an optimum at $85^{\circ} \mathrm{C}$. The circular dichroism spectrum was in agreement with the percentage of secondary structures characteristic of the metallo- $\beta$-lactamase $\alpha \beta \beta \alpha$ fold.
\end{abstract}

Running title: First characterization of CphAII

Keywords: metallo- $\beta$-lactamase, metallo- $\beta$-lactamase superfamily, phosphodiesterase, zinc, $\alpha \beta \beta \alpha$ fold

Abbreviations: MBL, metallo- $\beta$-lactamase; $p$-nitrophenyl sulfate, pNPS; $p$-nitrophenyl phosphate, pNPP; bis-p-nitrophenyl phosphate, bpNPP; p-nitrophenyl 5'-thymidine monophosphate, TpNPP; $p$-nitrophenylphosphorylcholine, pNPPC 


\section{INTRODUCTION}

The metallo- $\beta$-lactamase (MBL) superfamily was defined in 1997 (Neuwald et al., 1997). In addition to metallo- $\beta$-lactamases which cleave the amide bond of the $\beta$-lactam ring of penicillins, cephalosporins or carbapenems thus inactivating the antibiotic (Bebrone, 2007), the MBL superfamily includes enzymes which hydrolyze thiol-ester, phosphodiester and sulfuric ester bonds as well as oxidoreductases. The number of proteins identified as presenting the five MBL superfamily conserved motifs is rapidly increasing (currently, there are more than 18500). These enzymes, classified in seventeen families (Daiyasu et al., 2001), catalyse a variety of diverse reactions. Only nine of the seventeen protein groups proposed to contain a metallo- $\beta$-lactamase $\alpha \beta \beta \alpha$ fold have been characterized structurally, class B $\beta$ lactamases also called metallo- $\beta$-lactamases (MBLs) (group 1) (Carfi et al., 1995), glyoxalases II (group 2) (Cameron et al., 1999), rubredoxin oxidoreductases (group 3) (Frazao et al., 2000), the phosphorylcholine esterase Pce (group 9) (Garau et al., 2005), the methyl parathion hydrolase (group 15) (Dong et al., 2005), the $N$-acyl homoserine lactone hydrolase (group 12) (Liu et al., 2005), the alkylsulfatase from Pseudomonas aeruginosa SdsA1 (group 13) (Hagelueken et al., 2006), the tRNA3'-processing endoribonuclease tRNaseZ (group 4) (Ishii et al., 2005) and proteins members of the $\beta$-CASP family (groups 6 and 7) (Callebaut et al., 2002). Whereas $\beta$-lactamases were shown to be active with one or two zinc ions (Bebrone, 2007), active glyoxalase II requires two of them (Cameron et al., 1999) or a mixed zinc/iron binuclear active site (Wenzel et al., 2004) and rubredoxin:oxygen oxidoreductase contains two iron ions (Frazao et al., 2000). The structural and biochemical characterization of this emerging MBL superfamily is necessary. Indeed, a large number of hypothetical enzymes found in GenBank ${ }^{\mathrm{TM}}$ might also share this $\alpha \beta \beta \alpha$ fold and bind one or two metal ions, but most of the enzymes have not been functionally or structurally 
characterized yet. One of these hypothetical MBL proteins is the product of the cphAII gene in Aquifex aeolicus VF5 (GENBANK accession number $\underline{\mathbf{A E 0 0 0 6 5 7}}$, locus_tag = “aq_974”). A. aeolicus is a chemolithoautotrophic bacterium that thrives at temperatures higher than $85^{\circ} \mathrm{C}$ in environments containing only inorganic components and utilises gaseous hydrogen, carbon dioxide, and oxygen as substrates (Huber et al., 1992; Kawasumi et al., 1984). The complete genomic sequence of an A. aeolicus strain isolated from hydrothermal vents in Yellowstone National Park was determined by Deckert et al. (1998). The A. aeolicus CphAII protein sequence shows the five conserved motifs of the MBL superfamily namely Asp84, His116Xaa-His118-Xaa-Asp120-His121, His196, Asp221 and His263 (the standard numbering for class B $\beta$-lactamases -BBL- (Garau et al., 2004) is applied to CphAII and used throughout this paper) (Figure 1a). With the exception of Asp84, the other conserved residues are involved in metal coordination. Indeed, for the majority of the already characterized enzymes of the superfamily, the first metal ion binding site is composed of His116, His118 and His 196, Asp120, His121 and His263 form the second one. Asp221 and a water molecule bridge the two metallic ions (Bebrone, 2007).

CphAII (O67103_AQUAE) is annotated as a $\beta$-lactamase precursor in the Protein Knowledgebase UniProtKB. It presents $28 \%$ identity with the Aeromonas hydrophila subclass B2 CphA MBL (Hernandez Valladares et al., 1996, 1997, Vanhove et al., 2003; Bebrone et al., 2005, 2008, 2009) (Figure 1b) and $25 \%$ identity with the Pseudomonas aeruginosa subclass B1 SPM-1 MBL (Murphy et al., 2006). The percentage of identity between the three subclasses of "real" MBLs (B1, B2 and B3) also does not exceed $30 \%$. However, a major difference with "real" MBLs is that the CphAII sequence highlights the presence of an Asp residue in position 221 as in most members of the superfamily whereas a cysteine is found in B1 and B2 $\beta$-lactamases and a serine (or methionine in GOB-type enzymes) in B3 (Figure 1a). No enzymatic property was determined for the product of the 
cphAII gene from A. aeolicus. We produced this protein in Escherichia coli and purified it to homogeneity. We show here that this protein is not a $\beta$-lactamase, but exhibits a metaldependent phosphodiesterase activity versus bis-p-nitrophenyl phosphate (bpNPP) and thymidine 5'-monophosphate $p$-nitrophenyl ester (TpNPP), two small artificial chromogenic substrates. 


\section{EXPERIMENTAL}

\section{Bacterial strains and genetic materials}

E. coli $\mathrm{DH} 5 \alpha$ was used as the host for recombinant plasmids during plasmids construction. E.coli GI724 (Invitrogen) was used as the host for expression of the CphAII enzyme cloned in the pLex expression vector. pGEM T-easy vector (Promega) was used as the vector for cloning and confirmatory sequencing of the PCR-amplified $c p h A$ II gene. pLex (Invitrogen) and pLex-His vectors were used as the expression vectors for the production of the CphAII enzyme. This latter vector was a gift from Dr. A. Chahboune (CIP, University of Liège, Belgium) and was constructed as a modified pLex vector where the polylinker of pLex is replaced by the polylinker of the pET22b vector (Novagen). A. aeolicus VF5 genomic DNA was a gift from Dr. M. Ngyen-Distèche (CIP, University of Liège, Belgium).

\section{Cloning, Expression and Purification of CphAII}

To develop an expression system for overproduction of the CphAII enzyme, the $A$. aeolicus cphAII gene was cloned in the pLex-His vector as follows. The cphAII ORF was amplified by PCR from the A. aeolicus genomic DNA using primers 5'GGTTCTAACTTTCATATGGGAGGTGCGGTCATGTTAAAAACGC-3' and 5'CTCGAGAAGTTCTAAATCAAGTTCGTTGTAAACCTTCCACACGTTTGT-3' to obtain an amplification product containing the entire cphAII ORF flanked by restriction sites (NdeI and $X h o \mathrm{I}$ ), suitable for directional cloning in the polylinker of the pLex-His vector, downstream of the strong and highly regulated $\mathrm{P}_{\mathrm{L}}$ promoter carried by this vector. The PCR was performed with Taq polymerase (Promega, Heidelberg, Germany). Reaction conditions were as follows: denaturation for $1 \mathrm{~min}$ at $95^{\circ} \mathrm{C}$, annealing for $1 \mathrm{~min}$ at $63^{\circ} \mathrm{C}$, and extension for $2 \mathrm{~min}$ at $72^{\circ} \mathrm{C}$, repeated for 30 cycles. The amplification product was initially cloned in 
the pGEM vector, giving pGEM/CphAII, and subjected to sequencing to verify that the in vitro PCR step had not introduced unwanted mutations. The $\sim 900$ bp NdeI-XhoI insert of pGEM/CphAII was then subcloned in the pLex-His vector to obtain plasmid pLex/CphAIIHis.

The GI724 E.coli cells harbouring pLex/CphAII-His were grown overnight at $30^{\circ} \mathrm{C}$ in $60 \mathrm{ml}$ of RM medium (per litre: $20 \mathrm{~g}$ casamino-acids, $3 \mathrm{~g} \mathrm{KH}_{2} \mathrm{PO}_{4}, 0.5 \mathrm{~g} \mathrm{NaCl}, 6 \mathrm{~g} \mathrm{Na}_{2} \mathrm{HPO}_{4}$, $1 \mathrm{~g} \mathrm{NH}_{4} \mathrm{Cl}, 0.095 \mathrm{~g} \mathrm{MgCl}_{2}, 1 \%$ (v/v) glycerol) containing $100 \mu \mathrm{g} / \mathrm{ml}$ ampicillin as the selection agent. This initial culture was added to 2 litres of induction medium (per litre: $2 \mathrm{~g}$ casamino-acids, $3 \mathrm{~g} \mathrm{KH}_{2} \mathrm{PO}_{4}, 0.5 \mathrm{~g} \mathrm{NaCl}, 6 \mathrm{~g} \mathrm{Na}_{2} \mathrm{HPO}_{4}, 1 \mathrm{~g} \mathrm{NH} 4 \mathrm{Cl}, 0.095 \mathrm{~g} \mathrm{MgCl}_{2}, 5 \mathrm{~g}$ glucose) containing $100 \mu \mathrm{g} / \mathrm{ml}$ ampicillin. The culture was grown at $30^{\circ} \mathrm{C}$. At an $\mathrm{A}_{550}$ value of $0.5,20 \mathrm{ml}$ of $10 \mathrm{mg} / \mathrm{ml}$ tryptophan were added, and the culture grown for a further $20 \mathrm{~h}$.

The bacteria were harvested by a 15 min centrifugation at $5000 \mathrm{x} g$ at $4^{\circ} \mathrm{C}$. The pellet was resuspended in $60 \mathrm{ml}$ of $50 \mathrm{mM}$ sodium phosphate buffer $\mathrm{pH} 8.0$, containing $250 \mathrm{mM}$ $\mathrm{NaCl}$ (buffer A1) and subjected to cellular disruption (EmulsiFlex C5, Avestin, Mannheim, Germany). Cell lysates were then centrifuged at $30000 \times \mathrm{g}$ for $30 \mathrm{~min}$ at $4^{\circ} \mathrm{C}$. The resulting supernatant was heated at $80^{\circ} \mathrm{C}$ for $10 \mathrm{~min}$ to denature thermolabile E. coli proteins, and placed on ice for $30 \mathrm{~min}$ to aggregate the denatured proteins. The supernatant was separated from the precipitated proteins by centrifugation at $30000 \mathrm{x} g$ for $30 \mathrm{~min}$ at $4^{\circ} \mathrm{C}$. The cleared supernatant was dialyzed overnight at $4^{\circ} \mathrm{C}$ against $5 \mathrm{~L}$ of buffer $\mathrm{A} 1$ and then loaded onto a 5 ml HisTrap ${ }^{\mathrm{TM}}$ HP (Amersham Biosciences) equilibrated with the same buffer. The column was washed with buffer A1 and the protein eluted with an imidazole gradient (0-300 mM). The fractions containing CphAII were collected, pooled, diluted 6-fold in buffer A1 and then loaded onto a $1 \mathrm{ml}$ HisTrap ${ }^{\mathrm{TM}}$ HP column (Amersham Biosciences) equilibrated with the same buffer. The column was washed with buffer A1 and eluted with an imidazole gradient (0-300 mM). The fractions containing CphAII were collected, pooled, dialyzed against buffer 
A1 and concentrated by ultrafiltration with an Amicon ultrafiltration apparatus using an YM10 membrane. The protein sample was concentrated to $1 \mathrm{mg} / \mathrm{ml}$, as determined by the Bradford assay (Fermentas) or by measuring the absorbance at $280 \mathrm{~nm}\left(\mathrm{~A}_{280}{ }^{1 \mathrm{mg} / \mathrm{ml}}=1.48\right)$. $0.02 \%(\mathrm{w} / \mathrm{v})$ sodium azide was added to the protein solution. No activity was lost after prolonged storage at $4^{\circ} \mathrm{C}$ (several months).

To evaluate the influence of the C-terminal His-Tag on the zinc binding, CphAII was also produced without this added His-Tag. To do so, cphAII was cloned using primers (5'GGTTCTAACTTTCATATGGGAGGTGCGGTCATGTTAAAAACGC-3' and 5'CCATAACGTGGATCCTCAAAGTTCTAAATCAAGTTCGTTGTA-3') introducing restriction sites for $N d e I$ and $B a m H I$, respectively. PCR conditions and sub-cloning in pGEM were as described above. The gene coding for CphAII was then cloned into the NdeI and BamHI sites of the original pLex vector, yielding pLex/CphAII. Production of the CphAII protein was obtained from GI724 E.coli cells harbouring the pLex/CphAII vector, following the protocol described above. CphAII without added His-Tag was purified by a combination of heating and ion-exchange chromatography. Briefly, the bacterial suspension was pelleted, resuspended in $60 \mathrm{ml}$ of MES $10 \mathrm{mM} \mathrm{pH} 5.5$ (buffer A2) and then disrupted and clarified by centrifugation. The resulting supernatant was heated at $80^{\circ} \mathrm{C}$ for $10 \mathrm{~min}$, and then placed on ice for $30 \mathrm{~min}$. After centrifugation at $30000 \times \mathrm{g}$ for $30 \mathrm{~min}$ at $4^{\circ} \mathrm{C}$, the supernatant was dialyzed against buffer A2, loaded onto an SP-sepharose FF column pre-equilibrated with the same buffer and the CphAII protein was eluted with a linear $\mathrm{NaCl}$ gradient (0 to $0.5 \mathrm{M}$ ). Fractions containing CphAII were pooled, concentrated to $1 \mathrm{mg} / \mathrm{ml}$ and dialyzed overnight against buffer $\mathrm{A} 1$ at $4^{\circ} \mathrm{C}$.

\section{Gel filtration}


To determine whether purified CphAII was in mono- or oligomeric form and to determine its molecular mass, the protein was loaded onto a Superdex 75 GL 10/300 column previously calibrated with insulin (5800 Da), chicken lysozyme (14300 Da), trypsin inhibitor (21500 Da), carbonic anhydrase (31000 Da), chicken egg ovalbumin (45000 Da), bovine albumin (66200 Da) and dextran blue (2000000 Da) as molecular mass standards. The flow rate of buffer A was $0.2 \mathrm{ml} / \mathrm{min}$. Approximately $200 \mu \mathrm{g}$ of CphAII in $0.2 \mathrm{ml}$ were applied to the column.

\section{Gel electrophoresis}

Sodium dodecyl sulfate-polyacrylamide gel electrophoresis (SDS-PAGE) was performed according to the protocol of Laemmli (1970) with 5\% stacking and 15\% resolving gels using a Mini Protean III Biorad system. Protein bands were stained with Coomassie brilliant blue R-250 (Fluka, Buchs, Switzerland), and the molecular mass of the purified CphAII was determined by comparing its relative mobility to those of standard protein markers (Unstained Protein Molecular Weight Marker, Fermentas).

\section{Determination of the total-mass by mass spectrometry}

The mass of CphAII was determined by the ESI MS mass spectrometric method (Micromass Electrospray Q-Tof-2, Waters Corporation, MA, USA). The deconvolution was performed with the Maxent 1, Masslynx 4.0 program (Waters Corporation, MA, USA).

\section{Protein identification}

The N-terminal sequence of the purified protein was determined with the help of a gas-phase sequencer (Prosite 492 prosite sequencer, Applied Biosystems, Forster City, California). 


\section{Circular dichrö̈sm}

Circular dichroism spectra were recorded using a J-810 CD spectropolarimeter (Jasco). The spectra were scanned at $25^{\circ} \mathrm{C}$ with $1 \mathrm{~nm}$ steps from 185 to $260 \mathrm{~nm}$ (far UV). 37 $\mu \mathrm{g}$ of purified CphAII were used in $300 \mu \mathrm{l}$ of $10 \mathrm{mM}$ sodium phosphate buffer $\mathrm{pH} 8.0$ in a 1 mm quartz cuvette. Deconvolution of the CD spectra was performed using the CDSSTR program and the protein data sets no. 4 and 7 , found in DICHROWEB, a facility of the Biotechnology and Biological Sciences Research Council Centre for Protein and Membrane Structure and Dynamics (Whitmore and Wallace, 2008). The thermal stability of CphAII was assessed by increasing the temperature from 25 to $95^{\circ} \mathrm{C}$ and monitoring the ellepticity at 220 nm.

Determination of the zinc content by inductively coupled plasma mass spectrometry $(I C P / M S)$

Three millilitres samples of CphAII $(15 \mu \mathrm{M})$ were dialyzed against $50 \mathrm{mM}$ sodium phosphate buffer $\mathrm{pH} 8.0$ prepared with MilliQ water $([$ Zinc $]<0.4 \mu \mathrm{M})$ or with $100 \mu \mathrm{M}$ zinc. An aliquot of the final dialysis buffer was saved for ICP/MS analysis of background zinc ion content. Protein concentrations were determined by the Bradford assay (Fermentas) or by measuring the absorbance at $280 \mathrm{~nm}$. Zinc concentrations were measured by inductively coupled plasma mass spectroscopy (ICP/MS) at the Malvoz Institute (Liège, Belgium). The metal/enzyme ratio was calculated from the differences of metal concentration between the 
enzyme sample and the dialysis buffer. The enzyme preparation was also analyzed for the presence of some other divalent metals (cobalt, copper, manganese, nickel and iron).

\section{Activity screening}

General enzymatic screens for various activities (phosphatase, phosphodiesterase, esterase, protease, dehydrogenase and oxidase) were performed in microplates at 21 and 70 ${ }^{\circ} \mathrm{C}$ as previously described (Miller et al., 2007; Kuznetsova et al., 2005; Chen et al., 2004; Yakunin et al., 2004). Moreover, several substrates of proteins which belong to the MBL superfamily were tested. Activity tests were performed in microplates in $150 \mu 1$ of buffer A1. The colour change from yellow to red due to the hydrolysis of nitrocefin $(100 \mu \mathrm{M})$, a chromogenic $\beta$-lactamase substrate, was detected by eye. Carbapenemase and penicillinase activities using the substrates imipenem $(100 \mu \mathrm{M})$ and ampicillin $(1 \mathrm{mM})$ were monitored at 300 and 235 nm, respectively, using a Power Wave X (Bio-Tek instruments, INC.) microplate spectrophotometer. Liberation of $p$-nitrophenol from $p$-nitrophenyl sulfate (pNPS), $p$ nitrophenyl phosphate (pNPP), bis- $p$-nitrophenyl phosphate (bpNPP) or thymidine 5'monophosphate $p$-nitrophenyl ester (TpNPP) (10 mM) was eye-detected by appearance of a yellow colour while the hydrolysis of $p$-nitrocatechol sulfate $(10 \mathrm{mM})$ was eye-detected by a colour change from yellow to red. Glyoxalase II activity using the substrate $S$-Dlactoylglutathione $(0.5 \mathrm{mM})$ was monitored at $240 \mathrm{~nm}$ using a Power Wave X microplate spectrophotometer. All reactions were carried out at $21^{\circ} \mathrm{C}$ and monitored for $24 \mathrm{~h}$. The reactions were also performed at $85^{\circ} \mathrm{C}$. Negative controls were conducted without added enzyme. The alkylsulfatase activity of CphAII was also tested against the standard substrate rac-octyl-2-sulfate.

For phosphodiesterases, there are three main groups of natural substrates: cyclic nucleotides, nucleic acids and phospholipids. Phosphohydrolase activities against these 
substrates were then assayed using published protocols (Vogel et al., 2002; Chen et al., 2004; Podzelinska et al., 2009) and commercially available compounds. In brief, hydrolysis of DNA (single- and double-stranded) was inspected by analyzing reaction products by agarose gel electrophoresis. Hydrolysis of yeast RNA was analyzed by following the absorption change at $260 \mathrm{~nm}$ for $30 \mathrm{~min}$ after addition of CphAII. Hydrolysis of cyclic nucleotides $\left(2^{\prime}-3^{\prime}\right.$-cAMP, $\left.2^{\prime}-3^{\prime}-\mathrm{cGMP}, 3^{\prime}-5^{\prime}-\mathrm{cCMP}\right)$ was probed using Sigma alkaline phosphatase and malachite green reagent to detect the released inorganic phosphate. Reactivity with pyrophosphate, AMP, ADP, ATP was investigated by detection of released phosphate using molybdate/malachite green reagent. Phospholipase $\mathrm{C}$ activity was analyzed using $10 \mathrm{mM} \quad p$ nitrophenylphosphorylcholine (pNPPC). Release of $p$-nitrophenolate was monitored at 405 nm. Phospholipase D activity against phosphatidylcholine was probed using choline oxidase (Sigma) and the peroxidase dianisine-coupled assay for oxidase testing (Kelley and Reddy, 1988).

\section{Phosphodiesterase assay for kinetic analysis.}

The hydrolysis of the chromogenic phosphodiesterase substrate (bpNPP or TpNPP) was monitored by following the absorbance variation at $405 \mathrm{~nm}$, using an Uvikon 860 spectrophotometer equipped with thermostatically controlled cells and connected to a microcomputer.

Optimum temperature for the activity of the purified protein sample was determined by measuring the initial hydrolysis rates over the temperature range of $20-90^{\circ} \mathrm{C}$ with $10 \mathrm{mM}$ bpNPP as the substrate. The exact temperature in the cell was verified with the help of a thermocouple.

The effect of $\mathrm{pH}$ and buffers on the activity versus $10 \mathrm{mM}$ bpNPP was studied by measuring the initial hydrolysis rates at $85^{\circ} \mathrm{C}$. The effect of $\mathrm{pH}$ and buffers on the stability of the enzyme was also investigated. The following buffers were used (the concentration of the 
buffering component was $50 \mathrm{mM}$ in all cases): sodium acetate ( $\mathrm{pH} \mathrm{5,} \mathrm{5.5,} \mathrm{6),} \mathrm{KH}_{2} \mathrm{PO}_{4}(\mathrm{pH} 6)$, sodium cacodylate ( $\mathrm{pH}$ 6, 6.5), HEPES ( $\mathrm{pH} 7,7.5,8)$, Tris ( $\mathrm{pH} 7.4,8$ and 8.5) and sodium

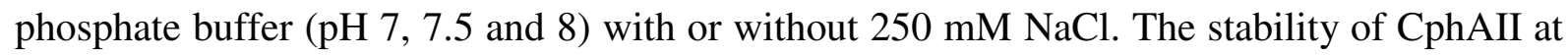
50 and $85^{\circ} \mathrm{C}$ was also evaluated by measuring the activity of the enzyme versus $10 \mathrm{mM}$ bpNPP after different incubation times at these two temperatures.

The $\mathrm{k}_{\mathrm{cat}}$ and $\mathrm{K}_{\mathrm{m}}$ parameters were determined under initial-rate conditions, using the Hanes linearization of the Henri-Michaelis-Menten equation. The kinetic parameters $\left(\mathrm{k}_{\mathrm{cat}}, \mathrm{K}_{\mathrm{m}}\right.$, $\left.\mathrm{k}_{\mathrm{cat}} / \mathrm{K}_{\mathrm{m}}\right)$ were determined in buffer $\mathrm{A} 1$ at two different temperatures $\left(21\right.$ and $\left.85^{\circ} \mathrm{C}\right)$.

Enzymatic measurement in the presence of increasing concentrations of cobalt or zinc and determination of $K_{D 2}$

Relative activity in the presence of increasing concentrations of cobalt or zinc was measured at $85^{\circ} \mathrm{C}$ in buffer A1. Both metal ions are soluble in the phosphate buffer at least up to the highest tested concentration $(500 \mu \mathrm{M})$. Binding of the second metal ion resulted in an increase of activity and Equation 1 was used:

$\mathrm{RA}=\left[\left(\mathrm{K}_{\mathrm{D} 2}+\alpha[\mathrm{M}]\right) /\left([\mathrm{M}]+\mathrm{K}_{\mathrm{D} 2}\right)\right] \times 100 \quad($ Eq. 1)

where RA is the relative activity and $\mathrm{K}_{\mathrm{D} 2}$ the dissociation constant for the second metal ion, $\alpha$ represents the ratio of activity at saturating metal concentration versus activity in the absence of added metal (Act. $[\mathrm{M}]_{(\infty)} /$ Act. $\left.[\mathrm{M}]_{(0)}\right)$.

Experimental data were fitted to Eq.1 by non-linear regression analysis with the help of the Sigma Plot software. 


\section{RESULTS}

\section{Production of the A. aeolicus CphAII protein in E. coli}

E.coli GI724 were transformed by plasmid pLex/CphAII-His and the production of the CphAII protein by the transformed strain was monitored as a function of time after induction by tryptophan at $37^{\circ} \mathrm{C}, 30^{\circ} \mathrm{C}$ or $18^{\circ} \mathrm{C}$. Results showed that the maximal production was achieved after $20 \mathrm{~h}$ of growth at $30^{\circ} \mathrm{C}$. In these conditions, expression of CphAII in fusion with a C-terminal His-Tag in E. coli yielded $\sim 5 \mathrm{mg} /$ litre of soluble recombinant protein. Assays to improve the quantity of produced recombinant CphAII protein with the help of various surexpression pET systems (pET9a, pET26b, pET28a from Novagen) and E.coli host strains (BL21(DE3), C41 or KRX) in LB, 2XYT or Studier's induction media did not succeed (data not shown).

\section{Purification of the recombinant CphAII}

The enzyme was purified from the soluble fraction of E. coli GI724 (cytoplasmic and periplasmic fractions) after $20 \mathrm{~h}$ of growth by heat-denaturation of contaminant E. coli proteins followed by two steps of nickel-affinity chromatography. Purified CphAII migrates as a $35 \mathrm{kDa}$ protein on SDS-PAGE, which corresponds well to the calculated molecular mass of the mature CphAII protein fused to the polyhistidine-tag. Western blot analysis with antiHis-tag antibodies confirmed the presence of the His-tag in the $\sim 35 \mathrm{kDa}$ band (data not shown). Moreover, in-gel tryptic digestion of the $\sim 35 \mathrm{kDa}$ band was performed. Mass spectrometric (MS) analysis of the trypsin-digested peptides confirmed that the purified protein was CphAII. The purified protein was confirmed to be in a monomeric form of about $35 \mathrm{kDa}$ by comparing its retention volume to those of standard proteins upon gel filtration chromatography. 
The N-terminal sequence predicted by the SignalP 3.0 program (Bendtsen et al., 2004) is MTLKK however the experimental N-terminal sequencing resulted in an unambiguous $\mathrm{N}$ terminal sequence of LIISTAF. The mature CphAII protein produced in E. coli had thus eight additional amino-acids at the $\mathrm{N}$-terminal when compared to the predicted mature enzyme (Figure 1b). Moreover, the mass of the protein verified by electrospray mass spectrometry corresponded within experimental error to the calculated mass for CphAII beginning at LIISTAF and in fusion with a LEHHHHH-peptide (His-tag) on the C-terminal (35101 versus $35099 \mathrm{Da})$.

\section{Recombinant CphAII produced in E. coli is able to bind zinc ions.}

After extensive dialysis against a $50 \mathrm{mM}$ sodium phosphate buffer $\mathrm{pH} 8.0$ containing less than $0.4 \mu \mathrm{M}$ free zinc, ICP/MS showed that the CphAII protein produced in E. coli contained one zinc ion per molecule. After extensive dialysis against a $50 \mathrm{mM}$ sodium phosphate buffer pH 8.0 containing $100 \mu \mathrm{M}$ zinc, CphAII bound a second zinc ion. As isolated, CphAII contained a His-tag which could not be removed. The absence of influence of a His-tag on the number of bound zinc ions as determined by ICP/MS has already been demonstrated with two others proteins of the superfamily, ZiPD and the cytosolic oxygen reductase from E. coli (Vogel et al., 2002). Nevertheless, to verify that the His-tag had no influence on the number of zinc ions bound by CphAII, the protein was also produced from the original $\mathrm{pLex}$ vector and purified without the tag. The yield of this purification was very low and the quantity of pure CphAII obtained was only sufficient to carry out the same zinc content measurements which confirmed the data obtained with the His-tagged enzyme (Table 1). Other metallic ions such as cobalt, copper, manganese, iron and nickel were not found.

\section{CphAII possesses a phosphodiesterase activity}


Based on the sequence identity with the CphA and SPM-1 MBLs, we probed CphAII first for $\beta$-lactamase activity using carbapenem, penicillin and cephalosporin substrates. No activity toward these substrates could be detected at $21^{\circ} \mathrm{C}$. At $85^{\circ} \mathrm{C}$, these antibiotic compounds were too unstable to perform accurate kinetics measurements. However, the addition of the enzyme did not increase the hydrolysis rate.

Also, CphAII was probed for enzymatic activity (phosphatase, phosphodiesterase, nuclease, esterase, protease, dehydrogenase, oxidase and sulfatase) using several general enzymatic assays. Particularly, compounds modified by other enzymes of the MBL superfamily were tested including glyoxalase II, arylsulfatase, phosphatase and phosphodiesterase substrates. Two phosphodiester substrates were identified: TpNPP (thymidine 5'-monophosphate pnitrophenyl ester) and bpNPP (bis-para-nitrophenyl-phosphate). bpNPP was a much better substrate. It was cleaved into $p$-nitrophenol and $p$-nitrophenyl phosphate. The latter product was also tested as substrate and was not further hydrolysed by the enzyme. This enzyme is therefore a phosphodiesterase and does not act on phosphomonoesters.

Various $\mathrm{pH}$ and buffers were assayed for the stability and the activity. The stability and the phosphodiesterase activity were maximal in $50 \mathrm{mM}$ sodium phosphate buffer $\mathrm{pH} 8.0$, containing $250 \mathrm{mM} \mathrm{NaCl}$. The enzyme was stable at $50^{\circ} \mathrm{C}$ for more than $24 \mathrm{~h}$ and at least $3 \mathrm{~h}$ at $90^{\circ} \mathrm{C}$.

The phosphate buffer, thanks to its low thermal coefficient, is ideal to work at high temperature (its $\mathrm{pH}$ only slightly varies with temperature when compared to organic buffers such as Tris). In this buffer, the recombinant CphAII protein showed activity toward the generic phosphodiesterase substrate bpNPP, with a $k_{\text {cat }}$ value of $0.02 \mathrm{~s}^{-1}$ and a $K_{m}$ value of 6 $\mathrm{mM}$ when assayed at $21^{\circ} \mathrm{C}$ (Figure 2). The CphAII phosphodiesterase activity increased at higher temperatures, reaching a $\mathrm{k}_{\mathrm{cat}}$ of $1 \mathrm{~s}^{-1}$ with a $\mathrm{K}_{\mathrm{m}}$ of $5 \mathrm{mM}$ at $85^{\circ} \mathrm{C}$ (Figure 2). 
As ZiPD (Vogel et al., 2002), CphAII hydrolyzed TpNPP, another general phosphodiesterase substrate, at a significantly lower rate than bpNPP. Indeed, the yellow colour resulting from the presence of $p$-nitrophenol only appeared after an overnight incubation with the enzyme at $21^{\circ} \mathrm{C}$. At $85^{\circ} \mathrm{C}$, CphAII hydrolyzed TpNPP with a $\mathrm{k}_{\text {cat }}$ of $0.2 \mathrm{~s}^{-}$ ${ }^{1}$ and a $\mathrm{K}_{\mathrm{m}}$ of $14 \mathrm{mM}$ (Figure 2).

CphAII exhibited neither phosphodiesterase activity with the cyclic nucleotides tested $\left(2^{\prime}, 3^{\prime}-\right.$ cCMP, $3^{\prime}, 5^{\prime}$-cAMP or $3^{\prime}, 5^{\prime}$-cGMP), nor nuclease activity with various substrates (single- or double-stranded DNA, RNA), nor phospholipase activity towards phosphatidylcholine. Also, no cleavage of pyrophosphate, AMP, ADP or ATP was detected after incubation with CphAII. At $85{ }^{\circ} \mathrm{C}$, CphAII showed a very low but detectable activity versus pNPPC (phosphodiesterase/phospholipase C substrate). The yellow colour due to the liberation of the p-nitrophenol only appeared after four hour incubation with $5 \mu \mathrm{M} \mathrm{CphAII.}$

\section{The activity of CphAII is metal-dependent}

At $85^{\circ} \mathrm{C}$, zinc and cobalt ions showed activating effects on the activity of CphAII versus bpNPP. The phosphodiesterase activity increased upon addition of zinc or cobalt ions to the mono-zinc form. The determined $\mathrm{K}_{\mathrm{D} 2}$ values for the binding of the second metal ion were 16 and $1.3 \mu \mathrm{M}$ for zinc and cobalt, respectively. Saturating concentrations of the metal ions resulted in 1.4 and 1.9 fold activity increases with zinc and cobalt, respectively.

CphAII was more than $99 \%$ inactivated by the loss of the metal after 1-hour incubation with $10 \mathrm{mM}$ EDTA. After subsequent removal of EDTA by three successive cycles of dilution/concentration with buffer A1 beforehand treated with CHELEX (Sigma),

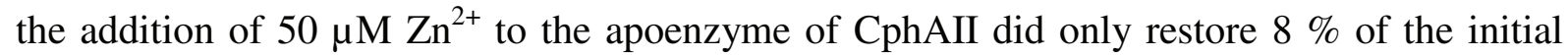
activity versus $30 \%$ with $50 \mu \mathrm{M} \mathrm{Co}^{2+}$. 


\section{Structural studies}

The room temperature far-UV CD spectrum of CphAII exhibited 2 local minima at $208 \mathrm{~nm}$ and $218 \mathrm{~nm}$. CphAII is primarily an $\alpha / \beta$ protein: the helical, $\beta$-sheets, turns and unordered contents predicted using the CDSSTR simulation program were 30, 22, 20 and 28 $\%$, respectively (Figure 3). These data are similar to the values previously obtained using the same simulation program for the Bacillus cereus metallo- $\beta$-lactamase (BcII) (30\% $\alpha$-helix, $20 \% \beta$-strand, $19 \%$ turns and $31 \%$ disordered) (Jacquin et al., 2009) and with the X-ray data available for CphA (i.e., $29 \% \alpha$-helix and $24 \% \beta$-strand, calculated in the Research Collaboratory for Structural Bioinformatics Protein Data Bank, using the 1X8G Protein Data Bank structure).

We attempted to obtain values for the apparent melting temperatures $\left(T_{\mathrm{m}}\right)$ for the protein by measuring the ellipticity at $222 \mathrm{~nm}$ upon heating of the samples from $25^{\circ}$ to $95^{\circ} \mathrm{C}$. The CphAII protein showed a gradual but steady loss of signal, and post-transition baselines could not be established $\left(T_{\mathrm{m}}\right.$ values $\left.>95^{\circ} \mathrm{C}\right)$. In presence of $10 \mathrm{mM}$ EDTA, the $\mathrm{T}_{\mathrm{m}}$ value was also above $95^{\circ} \mathrm{C}$. 


\section{DISCUSSION}

In this study, we developed an overexpression system in E. coli for the A. aeolicus CphAII protein, as well as a simple protocol based on the presence of a His-tag for purification of the recombinant enzyme. A first characterization of the enzyme was performed.

Sequence alignment shows that CphAII belongs to the MBL superfamily (Bebrone, 2007; Daiyasu et al., 2001; Aravind, 1999; Neuwald, 1997), which suggests that CphAII possesses two metal binding sites. Indeed, CphAII contains the five conserved motifs of the MBL superfamily, namely Asp84, His116-Xaa-His118-Xaa-Asp120-His121, His 196, Asp221 and His263. In the structurally characterized members of the superfamily and with the exception of Asp84, all these conserved residues participate in metal binding. We have shown here that CphAII purifies as a mono-zinc form from the soluble fraction of E. coli. Its activity is metal-dependent and both zinc and cobalt ions have a positive effect on the activity of CphAII. So, we cannot exclude that the cobalt-CphAII form could be naturally produced in the hyperthermophile A. aeolicus. The enzyme exhibits a higher activity after addition of cobalt to the mono-zinc form, which probably yields the $\mathrm{Zn} / \mathrm{Co}$ hybrid. This is often found with zinc containing proteins of the MBL superfamily. For example, in the subclass B1 Bacillus cereus MBL (BcII), cobalt is also more efficient than zinc for binding to the second site (Orellano et al., 1998). MBLs are able to function with cobalt (Lisa et al., 2010, Hawk et al., 2009) and the cobalt-substituted MBL from Bacillus cereus (BcII) is even a more efficient catalyst than the zinc native enzyme for the hydrolysis of some $\beta$-lactam antibiotics (Badarau et al., 2007). Also, the most active form of the human glyoxalase II, another member of the superfamily, is the cobalt-substituted form (Limphong et al., 2009)

The predicted percentage of helices and strands obtained using the deconvolution of the far-UV CD spectrum is in agreement with the content in $\alpha$ and $\beta$ structures of MBLs. 
Moreover, molecular modelling results confirmed the high probability of the $\alpha \beta \beta \alpha$ fold (data not shown).

Despite $28 \%$ and $25 \%$ identities with the subclass B2 CphA and the subclass B1 SPM-1 MBLs respectively, CphAII is not a $\beta$-lactamase but possesses a weak phosphodiesterase activity. The best substrate found here was the artificial bpNPP phosphodiester, while TpNPP was a significantly poorer substrate. Expectedly for an enzyme from a hyperthermophilic organism, the activity of CphAII is optimal at $85^{\circ} \mathrm{C}$. At the optimum, the kinetic $\mathrm{k}_{\mathrm{cat}}$ and $\mathrm{K}_{\mathrm{m}}$ constants of CphAII are similar to those previously determined for another member of the MBL superfamily, the E. coli K12 PhnP protein which is a phosphodiesterase of the carbon-phosphorus lyase pathway for phosphonate degradation (Podzelinska et al., 2009) (Table 2). Although the $\mathrm{k}_{\mathrm{cat}} / \mathrm{K}_{\mathrm{m}}$ value of CphAII for bpNPP (200 M$\left.{ }^{1} \mathrm{~s}^{-1}\right)$ is much lower than that of the ZiPD/ElaC phosphodiesterase from E.coli $\left(15000 \mathrm{M}^{-1} \mathrm{~s}^{-1}\right)$ (Vogel et al., 2002) (Table 2), it is one and two orders of magnitude higher those of Nuc (14 $\mathrm{M}^{-1} \mathrm{~s}^{-1}$,Zhao et al., 1997) and BfiI (4.2 $\mathrm{M}^{-1} \mathrm{~s}^{-1}$,Sapranauskas et al., 2000) nucleases, respectively. Note that $\mathrm{ZiPD/ElaC}$ is a binuclear zinc tRNAse $\mathrm{Z}$ which also belongs to the MBL superfamily (Schilling et al., 2005; Vogel et al., 2002).

In vitro, CphAII demonstrates metal-dependent phosphodiesterase activity versus artificial bpNPP and TpNPP substrates. A very low but detectable activity versus pNPPC (phosphodiesterase/phospholipase $\mathrm{C}$ chromogenic substrate) is also observed. In our studies, CphAII showed no nuclease activity against single- or double-stranded DNA or RNA. Moreover, no phosphohydrolase activity was found toward 2',3'- and 3',5'-cyclic nucleotides or phosphatidylcholine. The sequence of CphAII does not present the tRNAse Z-specific insertion of about $50 \mathrm{kD}$ located between His196 and Asp221 which is required for tRNA binding and pre-tRNA processing (Ishii et al., 2009, Schilling et al., 2005). With the exception of conserved motifs in the superfamily, CphAII does not present any sequence 
similarity with ZiPD/ElaC. Also, CphAII does not contain the $\beta$-CASP region specific to members of the MBL superfamily acting on nucleic acid substrates and involved in DNA repair and RNA processing (Callebaut et al., 2002). At the present time, the natural substrates(s) of CphAII remain(s) undetermined. It is however quite likely that this activity is highly specific. We are trying now to obtain the three-dimensional structure of CphAII in order to discuss these structural results in the context of its mechanism of action and biological function as a phosphodiesterase. 


\section{REFERENCES}

Aravind, L. 1999. An evolutionary classification of the metallo-beta-lactamase fold proteins. In Silico Biol. 1:69-91

Bebrone, C., Anne, C., De Vriendt, K., Devresse, B., Van Beeumen, J., Frère, J.M. and Galleni, M. 2005. Dramatic broadening of the substrate profile of the Aeromonas hydrophila CphA metallo- $\beta$-lactamase by site-directed mutagenesis, J. Biol. Chem. 17: 180-188

Bebrone, C. 2007. Metallo- $\beta$-lactamases (classification, activity, genetic organization, structure, zinc coordination) and their superfamily. Biochem. Pharmacol. 74: 1686-1701

Bebrone, C., Anne, C., Kerff, F., Garau, G., De Vriendt, K., Lantin, R., Devreese, B., Van Beeumen, J., Dideberg, O., Frère, J.M. and Galleni. M. .2008. Mutational analysis of the zinc and substrate binding sites in the $\mathrm{CphA}$ metallo- $\beta$-lactamase from Aeromonas hydrophila. Biochem. J. 114: 151-159

Bebrone, C., Delbrück, H., Kupper, M.B., Schlömer, P., Willmann, C., Frère, J.M., Fischer, R., Galleni, M. and Hoffmann, KM. 2009. The structure of the di-zinc subclass B2 metallo- $\beta$-lactamase CphA reveals that the second inhibitory zinc ion binds in the "histidine" site. Antimicrob. Agents Chemother. 53: 4464-71

Bendtsen, J.D., Nielsen, H., von Heijne, G. and Brunak, S. 2004. Improved prediction of signal peptides: SignalP 3.0. J. Mol. Biol. 340: 783-795

(http://www.cbs.dtu.dk/services/SignalP/)

Callebaut, I., Moshous, D., Mornon J.P., and de Villartay, J.P. 2002. Metallo-betalactamase fold within nucleic acids processing enzymes: the beta-CASP family. Nucleic Acids Res. 30: 3592-601

Cameron, A.D., Ridderstrom, M., Olin, B. and Mannervik, B. 1999. Crystal structure of human glyoxalase II and its complex with a glutathione thiolester substrate analogue. Structure Fold Des. 7: 1067-78 
Carfi, A., Pares, S., Duee, E., Galleni, M., Duez, C. Frère, J.M. and Dideberg, O. 1995 The 3-D structure of a zinc metallo-beta-lactamase from Bacillus cereus reveals a new type of protein fold. Embo J. 14: 4914-21

Chen, S., Yakunin, A.F., Kuznetsova, E., Busso, D., Pufan, R., Proudfoot, M., Kim, R. and Kim, S.H. 2004. Structural and functional characterization of a novel phosphodiesterase from Methanococcus jannaschii. J. Biol. Chem. 279: 31854-62

Daiyasu, H., Osaka, K., Ishino, Y. and Toh., H. 2001. Expansion of the zinc metallohydrolase family of the $\beta$-lactamase fold. FEBS Lett. 503: 1-6

Deckert, G., Warren, P.V., Gaasterland, T., Young,W.G., Lenox, A.L., Graham, D.E., Overbeek, R., Snead, M.A., Keller, M., Aujay, M., Huber, R., Feldman, R.A., Short, J.M., Olsen, G.J. and Swanson, R.V. 1998. The complete genome of the hyperthermophilic bacterium Aquifex aeolicus. Nature. 392: 353-358

Dong, Y.J., Bartlam, M., Sun, L., Zhou, Y.F., Zhang, Z.P., Zhang C.G., Rao, Z. and Zhang, X.E. 2005. Crystal structure of methyl parathion hydrolase from Pseudomonas sp. WBC-3. J. Mol. Biol. 353: 655-63

Frazao, C., Silva, G., Gomes, C.M., Matias, P., Coelho, R., Sieker L., Macedo, S., Liu, M.Y., Oliveira, S., Teixeira, M., Xavier, A.V., Rodrigues-Pousada , C., Carrondo, M.A. and Le Gall, J. 2000. Structure of a dioxygen reduction enzyme from Desulfovibrio gigas. Nat Struct Biol. 7: 1041-5

Garau, G., I. Garcia-Saez, C. Bebrone, C. Anne, P.S. Mercuri, M. Galleni, J.M. Frère, and Dideberg, O. 2004. Update of the standard numbering scheme for class B $\beta$-lactamases, Antimicrob.Agents Chemother. 48: 2347-2349.

Garau, G., Lemaire, D., Vernet, T., Dideberg O. and Di Guilmi, A.M. 2005. Crystal structure of phosphorylcholine esterase domain of the virulence factor choline-binding protein 
from Streptococcus pneumoniae: new structural features among the metallo-beta-lactamase superfamily. J. Biol. Chem. 280: 28591-600

Hagelueken G., Adams, T.M., Wiehlmann, L., Widow, U., Kolmar, H., Tümmler B., Heinz, D.W. and Schubert, W.D. 2006. The crystal structure of SdsA1, an alkylsulfatase from Pseudomonas aeruginosa, defines a third class of sulfatases. Proc. Natl. Acad. Sci. USA. 103: $7631-6$

Hernandez-Valladares, M., Galleni, M., Frère, J.M., Felici, A., Perilli, M., Franceschini, N., Rossolini, G.M., Oratore, A. and Amicosante, G. 1996. Overproduction and purification of the Aeromonas hydrophila CphA metallo-beta-lactamase expressed in Escherichia coli, Microbial Drug Resistance. 2: 253-256

Hernandez-Valladares, M., Felici, A., Weber, G., Adolph, H.W., Zeppezauer, M., Rossolini, G.M., Amicosante, G., Frère, J.M. and Galleni., M. 1997. Zn(II) dependence of the Aeromonas hydrophila AE036 metallo- $\beta$-lactamase activity and stability. Biochemistry. 36: $11534-11541$

Huber R., Wilharm T., Huber D., Trincone A., Burggraf S., König H., Rachel R., Rockinger I., Fricke H. and Stetter, K.O. 1992. Aquifex pyrophilus gen. nov, sp. nov., represents a novel group of marine hyperthermophilic hydrogen-oxidizing bacteria, Syst. Appl. Microbiol. 15: 340-351

Ishii, R., Minagawa, A., Takaku, H., Takagi, M., Nashimoto M. and Yokoyama S. 2005. Crystal structure of the tRNA 3' processing endoribonuclease tRNase Z from Thermotoga maritima. J. Biol. Chem. 280: 14138-44

Jacquin, O., Balbeur, D., Damblon, C., Marchot, P., De Pauw, E., Roberts, G.C., Frère, J.M. and Matagne, A. 2009. Positively cooperative binding of zinc ions to Bacillus cereus $569 / \mathrm{H} / 9$ beta-lactamase II suggests that the binuclear enzyme is the only relevant form for catalysis. J. Mol. Biol. 392: 1278-91 
Kawasumi T., Igarashi Y., Kodama T. and Minoda, Y. 1984. Hydrogenobacter thermophilus gen. nov, sp. nov., an extremely thermophilic, aerobic, hydrogen-oxidizing bacterium, Int. J. Syst. Bacteriol. 34: 5-10

Kelley, R. L. and Reddy, C. A. 1988. Glucose oxidase of Phanerochaete chrysosporium. Methods Enzymol. 161: 307-316

Kuznetsova, E., Proudfoot, M., Sanders, S.A., Reinking, J., Savchenko, A., Arrowsmith, C.H., Edwards, A.M. and Yakunin, A.F. 2005. Enzyme genomics: application of general enzymatic screens to discover new enzymes. FEMS Microbiol Rev. 29: 263-79

Liu, D., Lepore, B.W., Petsko, G.A., Thomas, P.W., Stone, E.M., Fast W. and Ringe, D. 2005. Three-dimensional structure of the quorum-quenching $\mathrm{N}$-acyl homoserine lactone hydrolase from Bacillus thuringiensis. Proc. Natl. Acad. Sci. USA. 102: 11882-7

Miller, D.J., Shuvalova, L., Evdokimova, E., Savchenko, A., Yakunin, A.F. and Anderson, W.F. 2007. Structural and biochemical characterization of a novel $\mathrm{Mn}^{2+}$-dependent phosphodiesterase encoded by the yfcE gene. Protein Sci. 16: 1338- 48.

Murphy, T.A., Catto, L.E., Halford, S.E., Hadfield, A.T., Minor, W., Walsh, T.R. and Spencer, J. 2006. Crystal structure of Pseudomonas aeruginosa SPM-1 provides insights into variable zinc affinity of metallo-beta-lactamases. J. Mol. Biol. 357: 890-903

Neuwald, A.F., Liu, J.S., Lipman, D.J. and Lawrence, C.E. 1997. Extracting protein alignment models from the sequence database. Nucleic Acids Res. 25: 1665-77

Orellano, E.G., Girardini, J.E., Cricco, J.A., Ceccarelli, E.A. and Vila, A.J. 1998. Spectroscopic characterization of a binuclear metal site in Bacillus cereus beta-lactamase II. Biochemistry. 37: 10173-80

Podzelinska, K., He, S.M., Wathier, M., Yakunin, A., Proudfoot, M., Hove-Jensen, B., Zechel, D.L. and Jia, Z. 2009. Structure of PhnP, a phosphodiesterase of the carbonphosphorus lyase pathway for phosphonate degradation. J. Biol. Chem. 284: 17216-26 
Sapranauskas, R., Sasnaukas, G., Lagunavicius, A., Vilkaitis, G., Lubys, A. and Siksnys, V. 2000. Novel subtype of type IIs restriction enzymes. BfiI endonuclease exhibits similarities to the EDTA-resistant nuclease Nuc of Salmonella typhimurium. J Biol Chem. 275: 30878-85

Schilling, O., Späth, B., Kostelecky, B., Marchfelder, A., Meyer-Klaucke, W. and Vogel, A. 2005. Exosite modules guide substrate recognition in the ZiPD/ElaC protein family., J. Biol. Chem. 280: 17857-17862

Vanhove, M., Zakhem, M., Devreese, B., Franceschini, N., Anne, C., Bebrone, C., Amicosante, G. Rossolini, G.M., Van Beeumen., J., Frère, J.M. and Galleni, M. 2003. Role of Cys221 and Asn116 in the zinc-binding sites of the Aeromonas hydrophila metallo- $\beta$ lactamase, Cell Mol Life Sci. 60: 2501-2509

Vogel, A., Schilling, O., Niecke, M., Bettmer, J. and Meyer-Klaucke, W. 2002. ElaC encodes a novel binuclear zinc phosphodiesterase. J. Biol. Chem. 277: 29078-29085

Wenzel, M., Carenbauer, A.L., Pfiester, M.P., Schilling, O., Meyer-Klaucke, W., Makaroff C.A. and Crowder, M.W. 2004. The binding of iron and zinc to glyoxalase II occurs exclusively as di-metal centers and is unique within the metallo- $\beta$-lactamase family. J. Biol. Inorg. Chem. 9: 429-38

Whitmore, L. and Wallace, B. A. 2008. Protein Secondary Structure Analyses from Circular Dichroism Spectroscopy: Methods and Reference Databases. Biopolymers 89: 392400

Yakunin, A.F., Proudfoot, M., Kuznetsova, E., Savchenko, A., Brown, G., Arrowsmith, C.H. and Edwards, A.M. 2004. The HD domain of the Escherichia coli tRNA nucleotidyltransferase has 2',3'-cyclic phosphodiesterase, 2'-nucleotidase, and phosphatase activities. J. Biol. Chem. 279: 36819-27 
Zhao, Y., Stuckey, J.A., Lohse, D.L. and Dixon, J.E. 1997. Expression, characterization, and crystallization of a member of the novel phospholipase D family of phosphodiesterases. Protein Sci. 6: 2655-8 


\section{ACKNOWLEDGEMENTS}

The work in Liège was supported by the Belgian Federal Government (PAI P5/33) and grants from the FRS/FNRS (Brussels, Belgium, FRFC grant $n^{\circ} 2.4511 .06$ and Lot. Nat. 9.4538.03). We thank Dr. D. Dehareng for her help in the modelling part. We thank P. Gadler (Department of Chemistry, Organic \& Bioorganic Chemistry, University of Graz, Graz, Austria) for testing the arylsulfatase activity of CphAII and N. Otthiers for the N-terminal sequencing of CphAII. We thank the Malvoz Institute (Province de Liège, BELGIUM) for the ICP/MS measurements. We thank Dr. Ch. Legrain (Institut de Recherches Microbiologiques J.-M. Wiame, Bruxelles, Belgium) for helpful discussions, scientific advices and for reviewing this manuscript. 


\section{LEGENDS TO FIGURE.}

Figure 1. a) Multiple alignment of representative MBL superfamily members, highlighting the five conserved motifs. MBLs from Bacillus cereus (BcII), Bacteroides fragilis (CcrA), Pseudomonas aeruginosa (VIM-2, SPM-1), Klebsiella pneumonia (NDM-1), Aeromonas hydrophila (CphA), Serratia fonticola (Sfh-1), Stenotrophomonas maltophilia (L1), Legionella gormanii (FEZ-1), Elizabethkingia meningoseptica (GOB-1). Non-MBLs superfamily members: human glyoxalase II (hGloII), rubredoxin:oxygen oxidoreductase from Desulfovibrio gigas (ROO), zinc dependent phosphodiesterase from Escherichia coli (ZIPD), phosphorylcholine esterase from Streptococcus pneumonia, phosphodiesterase of the carbonphosphorus lyase pathway from E. coli ( $\mathrm{PhnP})$, acyl-homoserine-lactone lactonase from Bacillus thuringensis (AiiA), alkylsulfatase from $P$. aeruginosa (SDSA1) and methylparathion hydrolase from Pseudomonas sp. (MPH). Available Protein data Bank accession codes are indicated. b) Sequence comparison between CphAII from Aquifex aeolicus and the subclass B2 CphA $\beta$-lactamase from Aeromonas hydrophila. The percentage of sequence identity is $28 \%$. The mature sequences are in bold black while the sequences of the signal peptides are in grey. The eight additional amino-acids at the Nterminal of CphAII when compared to the theoretical N-terminal sequence are in green. Identical residues are highlighted in pink and similar residues in cyan. The LEHHHHHH peptide was added at the C-terminal as a His-Tag to facilitate the purification (residues in blue).

Figure 2. a, c and e) The initial rate $\left(\mathrm{v}_{0}\right)$ versus substrate concentration (bpNPP (a and c) and TpNPP (e)), at $21^{\circ} \mathrm{C}$ (c) and $85^{\circ} \mathrm{C}$ (a and e). The reaction conditions were as described in "Experimental". Measurements were performed in triplicate. Experimental data were fitted to the Henri-Michaelis-Menten equation by non-linear regression analysis with the help of the 
SigmaPlot software. b, d and f) Hanes linearization of the kinetic data presented in a, c and e, respectively.

Figure 3. Far UV CD spectrum of CphAII. Deconvolution of the CD spectrum was performed using the CDSSTR program found in DICHROWEB (http://dichroweb.cryst.bbk.ac.uk/html/home.shtml). 


\section{Figure 1.}

a)

\begin{tabular}{|c|c|c|c|c|}
\hline \multirow[t]{5}{*}{ B1 } & Bcll & $1 \mathrm{BC} 2$ & LVDSS & ||$T H A H A D R \mid G G$ \\
\hline & CcrA & 1A7T & L L D T P & I P N HWHGDC I G G \\
\hline & VIM-2 & $1 \mathrm{KO} 3$ & L I D T A & $V S T H F H D D R G G$ \\
\hline & NDM-1 & $3 S B L$ & V V D T A & $V \vee T H A H Q D K M G$ \\
\hline & SPM-1 & $2 \mathrm{FHX}$ & VIVSS & I N T H F H L D G T G G \\
\hline \multirow[t]{2}{*}{ B2 } & CphA & $1 \times 8 \mathrm{H}$ & $V \vee G A T$ & I N T N Y H T DR A G G \\
\hline & Sfh-1 & $3 \mathrm{Q} 6 \mathrm{~V}$ & I I GAT & I NTNYHTDRA G G \\
\hline \multirow[t]{3}{*}{ B3 } & L1 & $1 \mathrm{SML}$ & L L D G G & $L L S H A H A D H G P$ \\
\hline & FEZ-1 & $1 \mathrm{~K} 07$ & L I NSD & LISHAHFDHAG \\
\hline & GOB-1 & & L I N T G & $L L T Q A H Y D H T G A$ \\
\hline Non- & hGloll & 1QH5 & I VDPV & L T THHHWDHAG \\
\hline \multirow[t]{8}{*}{ MBLs } & $\mathrm{ROO}$ & 1E5D & L F D T V & $V I Q H L E L D H A G A$ \\
\hline & ZIPD & $2 \mathrm{CBN}$ & LF DC G & $F \mid S H L H G D H L F G$ \\
\hline & Pce & 1WRA & $M \vee D T G$ & LVTHTHSDHIGN \\
\hline & PhnP & 3G1P & L I D A G & $L L T H Y H M D H \vee Q G$ \\
\hline & AiiA & 2A7M & L V D T G & I S SHLHFDHAGG \\
\hline & SDSA1 & 2CFU & V V D T L & I Y SHAHADHFGG \\
\hline & MPH & 1P9E & L V D T G & $Y I T H M H P D H G G$ \\
\hline & $\mathrm{Cpl}$ & & $T \mathrm{~T}$ & I VTHYHLDHWY \\
\hline
\end{tabular}

GKGHTED

GGGHAT D

G A A HST D

GPGHTSD

. GPAHSPD

G P A H T P D

GEAHTKD

MAGHTPG

TPGHTRG

. HPGHTKG

TPCHTSD

RM L HWPD

PLEHPLE

WDDNDNS

PLNHSKL

T P GHSPG

$P G T E S P A$

$S H G H T P G$

P PAHTN S
VGGCLVK.VPGHGE

FGGCMLK.VPGHGD

$Y G G C A \mid Y \ldots I P G H G L$

FGGCL I K.VMSHSA

FGGCMIK . I PGHGE

YGNC I LK. I GGHDS YGNC I LK. I AGHDT

YADSLSA. L TPHPG I I GS I GV . LGSHAG I ANMPSV.. VASHAS

FTGDTLF. YCGHEY I SNDIFG CPDHGV GPCDAAL . I I THVS LGGDLDN. FNHHHD WLSDTAG . I LTHIS LT I DASY FFGHD I LMAENVV.FA VHNW LLGDLIL . AASHLS F V GDLVY. L G GHNY

b) CphA MMKGWMKCGLAGAVVLMASFWGGSV_RAAGMSLTQVSGPVYVV....... EDNYYVQE

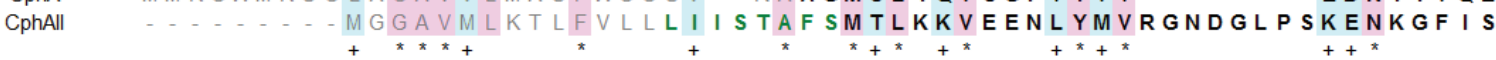

$\begin{array}{lllllll}\text { Standard numbering (BBL) } & 84 & & 116 & 118 & 12012\end{array}$

H

Motif 3
D

Motif 4

\section{H}

Motif 5
CphA

CphAll

CphA

CphAll

CphA

CphAll

CphA

CphAll

CphA

CphAll
Motif 1 K E N K
$+_{+}^{\star}$

NSMVYFGAKGVTVVGATWTPDTARELHKLIKRVSRKPVLEVINTNYHTDRAGGNAYWKS I NAYA VL TEEGWVVIDTLTTPELSEEFLNLLKKVSNKPVIYA I VTHYHLDHWYGAKTFKDK

GAKVVSTRQTRDLMKSDWA - E IVAFTRKGLPEYPD - LPLVLPNVVHDGDF TLQEGK - VRA GAKV I AHEKLKEFYDSGEALQVLEAQRKRFKGVLDSVELVPPDEVVKDKKVLKVGKDVFE $* * * *++++$

FYA - GPAHTPDGIFVYFPDEQVLY - GNCILKEK - - L LNLSFADVKAYPQTLERLKAMKL

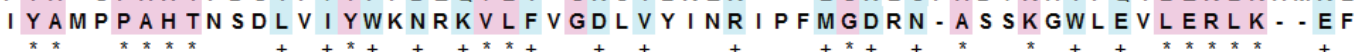
$t^{*}+t_{*}{ }_{*}+t_{*}{ }_{*} t_{+}$

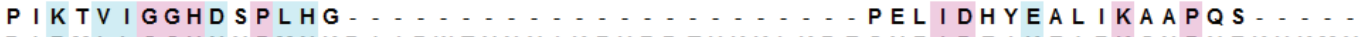
DARMLLGGHNYPMNKDA I DWTYNY I KFVRDTVKKLKDEGYFIDEIKEAFKGNPYEKVKMY $++t^{\star}{ }^{\star}{ }^{*}+{ }^{*}++$

EVFHNTNVWKVYNELDLELLEHHHHH 
Figure 2.
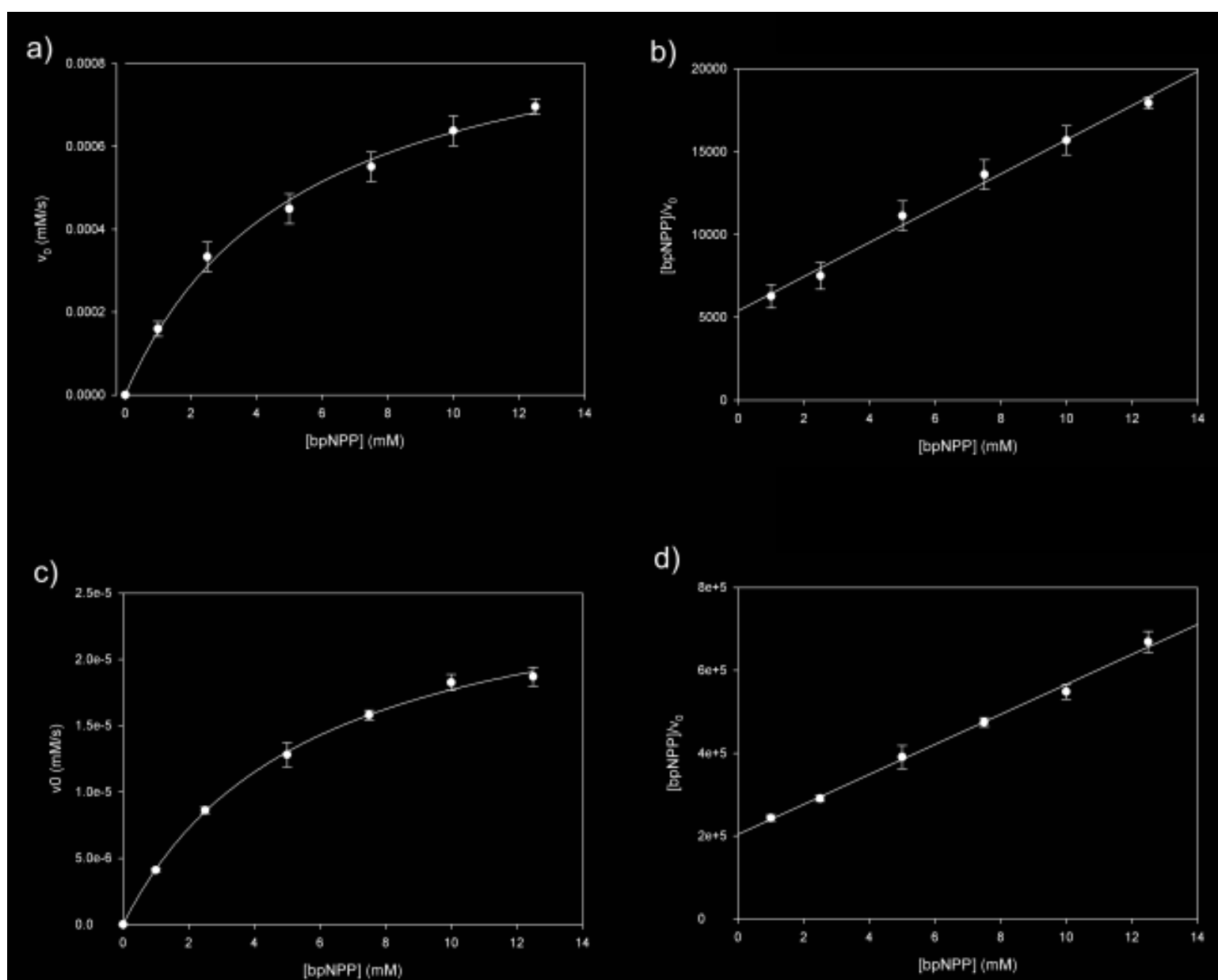

d)

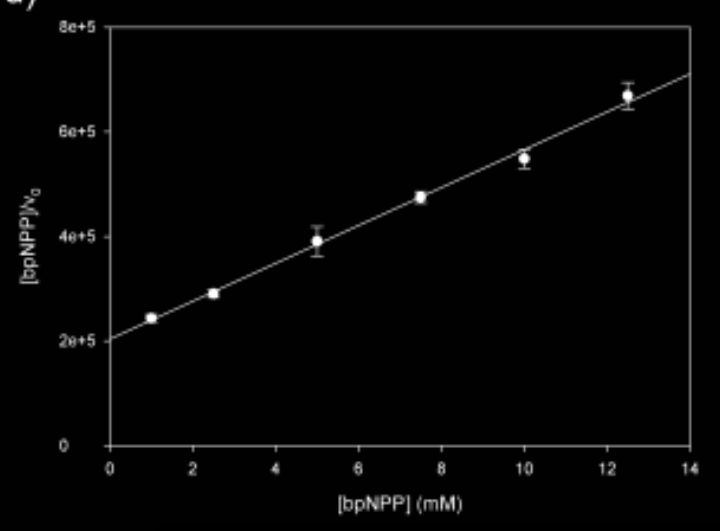

e)

f)
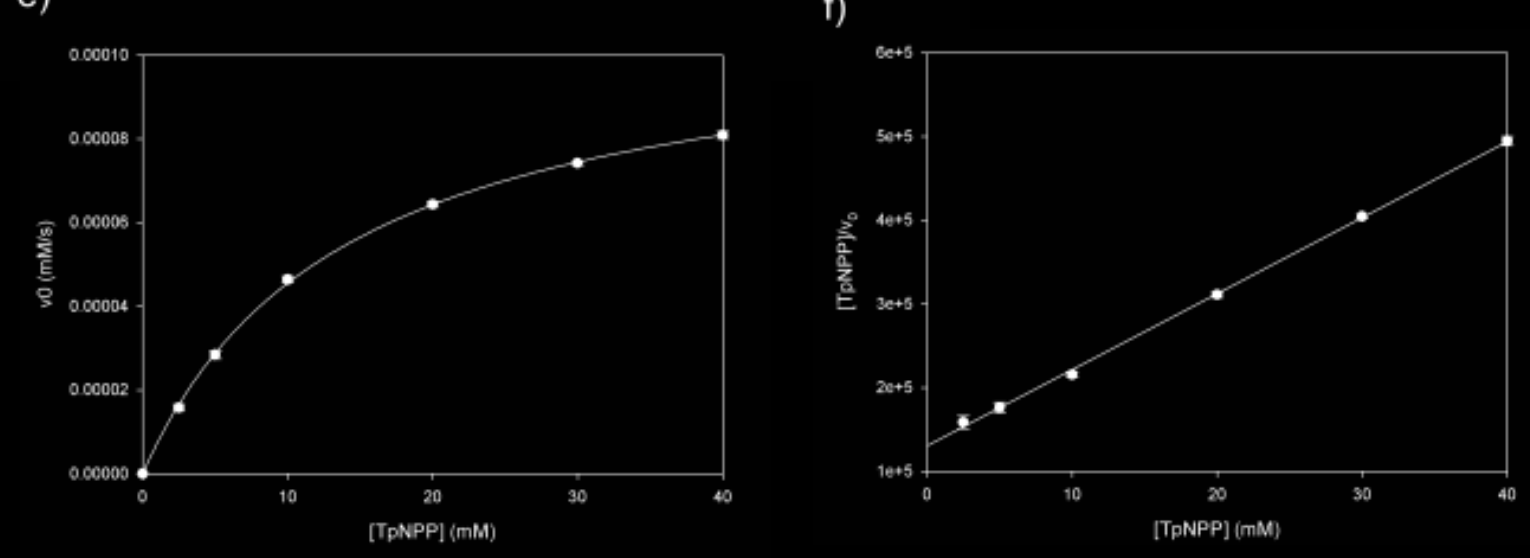
Figure 3.

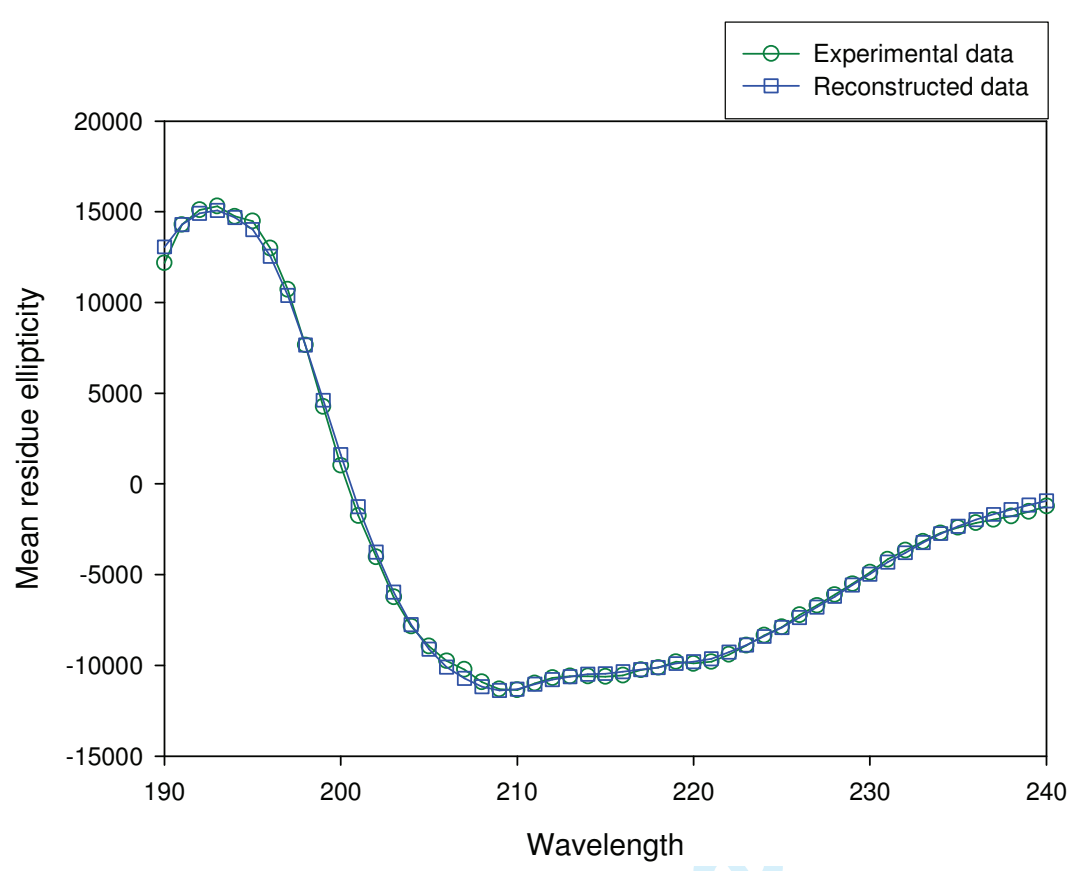

31

32

33

34

35

36

37

38

39

40

41

42

43

44

45

46

47

48

49

50

51

52

53

54 